\title{
Effect of Different Temperatures on Growth and Development of Trichogramma
}

\author{
Mohanisha Janghel*, P.C. Dash and K.C. Samal \\ Department of Entomology, Orissa University of Agriculture and Technology, \\ Bhubaneswar - 751003 (Odisha), India \\ *Corresponding author
}

\begin{tabular}{|l|}
\hline Ke y w o r d s \\
Trichogramma, \\
Parasitism, \\
Temperature
\end{tabular}

\section{Introduction}

Egg parasitoids (Trichogramma sp.,) offer an effective population regulation for lepidopteran pests especially for control of rice YSB and leaf folder (Hou et al., 2006; Yuan et al., 2012) Trichogramma egg parasitoids are important biological control agents and have been successfully used against a wide range of agricultural and forest pests for more than 70 years $(\mathrm{Li}, 1994)$.

World-wide, approximately 15 million ha of agricultural crops and forests are treated annually with large numbers of Trichogramma (van Lenteren, 2000). The study and uses of parasites, predators and pathogens for the regulation of host (pest) densities (DeBach, 1964) is need of the hour. In view of rich natural enemy complex of YSB and leaf folder incidence, it is necessary to select best bioagents which is effective for both pests.

\section{Materials and Methods}

One hundred parasitised eggs of Corcyra cepholonica by $T$. chilonis, T. japonicum were taken in closed polythene bags of $35 \times 30 \mathrm{~cm}$ having 300 guage thickness bags were kept in an incubator at four different temperature $\left(25^{\circ} \mathrm{C}, 28^{\circ} \mathrm{C}, 30^{\circ} \mathrm{C}\right.$ and $\left.32^{\circ} \mathrm{C}\right)$ for taking following observations at relative humidity (RH) of $75 \%$. The host eggs after turning black were counted for calculating \% 
parasitisation and \% emergence. The trial was replicated five times for conformity.

\% Parasitisation

No. of parasitised eggs in trichocards X 100

Total no. of eggs in tricho cards

Adult longevity $=$ Number of days until the death of adults

Development time $=$ Number of days required for development from egg to adult emergence from egg

Emergence \%

No. of adults emerged

$$
\begin{gathered}
\text { from trichocards } \times 100 \\
\text { Total no. of parasitised } \\
\text { eggs in tricho cards }
\end{gathered}
$$

The data obtained from recording of various activity of Trichogramma observed at different temperature from the laboratory studies were statistically analysed as per CRD design having five replications.

\section{Results and Discussion}

At $25^{\circ} \mathrm{C}$ the highest percent parasitisation, emergence ratio, adult longevity and development time was observed at different generations followed by 28,30 and $32^{\circ} \mathrm{C}$.

\section{T. chilonis}

The percent parasitisation by T.chilonis as shown in table 1 it was observed that out of four temperatures, the maximum was found at $25^{\circ} \mathrm{C}$ as $83.61 \%$. With the passing generations $\left(\mathrm{F}_{1}\right.$ to $\left.\mathrm{F}_{10}\right)$ a decrement was observed in percent parasitisation from 83.61 to $78.71 \%$. At $28^{\circ} \mathrm{C}$ the parasitisation percentage was observed from $80.40\left(\mathrm{~F}_{1}\right)$ to $76.54 \%\left(\mathrm{~F}_{10}\right)$ with each passing generations, at $30^{\circ} \mathrm{C}$ the parasitisation \% was observed as $\left(\mathrm{F}_{1}\right) 79.61$ to $71.25 \%\left(\mathrm{~F}_{10}\right)$ and at $32^{\circ} \mathrm{C}$ the parasitisation was observed as $\left(\mathrm{F}_{1}\right) 70.75$ to $62.25 \%\left(\mathrm{~F}_{10}\right)$. With the increase in temperature, the decrease in $\%$ parasitisation was observed. Moreover, this decrement in percent parasitisation was also been observed with subsequent generations $\left(\mathrm{F}_{1}\right.$ to $\left.\mathrm{F}_{10}\right)$. Yuan et al., (2012) also observed that the temperature and the humidity significantly affected the ability of all of the Trichogramma species to parasitise the eggs of their host. Garcia and Tavares (1994) found that $T$. chilonis parasitised more eggs at $26^{\circ} \mathrm{C}$ than at the other temperatures. A major effect of temperature on the population growth parameters is observed, a faster oviposition at higher temperatures will allow this pro-ovogenic parasitoid to lay most of its available eggs during a short lifetime period. Garcia and Tavares (1994) found significant differences between all temperatures for Trichogramma longevity, which increased with the decrease of temperature, results that are similar to ours. According to Jervis and Copland (1996) there is an optimal range of temperature for insect development, beyond which they would be unable to continue oogenesis and laying eggs or unable to function appropriately for a long period of time. This could be due to the increase in respiration rate, i.e., the insects would be unable to produce fertile eggs due to the high consumption of energy (Mills and Kuhlmann, 2000).

Development time from egg to adult at $25^{\circ} \mathrm{C}$ was observed between $\left(F_{1}\right) 2.67$ to 2.42 days $\left(\mathrm{F}_{10}\right)$, at $28^{\circ} \mathrm{C}$ the time taken was 2.32 to 2.46 days $\left(\mathrm{F}_{1}\right.$ to $\left.\mathrm{F}_{10}\right)$, at $30^{\circ} \mathrm{C}$ the development time was marked as 2.14 to 1.85 days $\left(\mathrm{F}_{1}\right.$ to $\left.\mathrm{F}_{10}\right)$ and at $32^{\circ} \mathrm{C}$ the duration was observed between 1.55 to 1.47 days ( $F_{1}$ to $F_{10}$ ). Development time needed by the Trichogramma strains was shorter as temperature increased. This finding is in agreement with Consoli and Parra (1995) who 
assumed that this might be due to a more appropriate metabolic process of the immature stages. The optimal temperature for development and survival was $25^{\circ} \mathrm{C}$ (McDougall and Mills 1997). However, the total mortality was greater at the higher temperature; these results are similar to the findings of Hawkins and Smith (1986). Pintureau and Bolland (2001) also found that as temperature increases, the duration of development decreases. Baitha et al., (2003) reported $25-33 \%$ parasitisation of $T$. japonicum at $25^{\circ} \mathrm{C}$ and up to $60 \%$ has been observed at $30^{\circ} \mathrm{C}$. There was an inverse relation between temperature and development of $T$. japonicum. The parasitism levels were higher when the average maximum temperature ranged from 27.9 to $29.4{ }^{\circ} \mathrm{C}$ and average minimum temperature ranged between 13.8 and $16.4{ }^{\circ} \mathrm{C}$ (Rao and Ali, 1977).

Emergence rate of adults from egg at $25^{\circ} \mathrm{C}$ was observed between 80.41 to $70.25 \%$ ( $\mathrm{F}_{1}$ to $\mathrm{F}_{10}$ ) emergence, at $28^{\circ} \mathrm{C}$ the emergence $\%$ was observed between $\left(\mathrm{F}_{1}\right) 73.57$ to $67.64 \%\left(\mathrm{~F}_{10}\right)$ at $30^{\circ} \mathrm{C}$ the emergence was seen between $\left(\mathrm{F}_{1}\right)$ 67.75 to $59.24 \%\left(\mathrm{~F}_{10}\right)$ and at $32^{\circ} \mathrm{C}$ the emergence was observed between 63.75 to $52.51 \%\left(\mathrm{~F}_{1}\right.$ to $\left.\mathrm{F}_{10}\right)$.

The adult longevity at $25^{\circ} \mathrm{C}$ was observed between $\left(\mathrm{F}_{1}\right) 3.45$ to $3.14\left(\mathrm{~F}_{10}\right)$ days at ten generations, at $28^{\circ} \mathrm{C}$ the longevity was observed as 3.17 to 2.55 days $\left(\mathrm{F}_{1}\right.$ to $\left.\mathrm{F}_{10}\right)$, at $30^{\circ} \mathrm{C}$ the longevity observed was between 2.57 to 1.97 days $\left(\mathrm{F}_{1}\right.$ to $\left.\mathrm{F}_{10}\right)$ and at $32^{\circ} \mathrm{C}$ the longevity observed was between $\left(\mathrm{F}_{1}\right) 1.55$ to $1.38\left(\mathrm{~F}_{10}\right)$ days. According to Nagarkatti and Nagaraja (1978), female fertility of Trichogramma wasps reared for a long time under laboratory conditions was significantly lower than that of wild females. However, female longevity is affected by many factors, such as temperature (Pak and Oatman, 1982), humidity (Stinner et al., 1974), host size (Stinner et al., 1974) and food. McDougall and Mills (1997) found that the high temperature could have caused sterilization of Trichogramma because they stopped laying eggs but lived for a few more days without laying new eggs. Also a reduction in female longevity was recorded from 5.3 days at $10^{\circ} \mathrm{C}$ and 3 days at $35^{\circ} \mathrm{C}$.

\section{T. japonicum}

Data on table 2 represents the percent parasitisation at $25^{\circ} \mathrm{C}$ was observed highest between $\left(\mathrm{F}_{1}\right) 82.12 \%$ to $69.25 \%\left(\mathrm{~F}_{10}\right)$, at $28^{\circ} \mathrm{C}$ the percent parasitisation was observed between 75.03 to $60.75 \%\left(\mathrm{~F}_{1}\right.$ to $\left.\mathrm{F}_{10}\right)$, at $30^{\circ} \mathrm{C}$ the parasitisation was observed between 63.51 to $51.50 \%\left(\mathrm{~F}_{1}\right.$ to $\left.\mathrm{F}_{10}\right)$ and at $32^{\circ} \mathrm{C}$ the parasitisation was observed between $42.75 \%$ to $53.21\left(\mathrm{~F}_{1}\right.$ to $\left.\mathrm{F}_{10}\right)$.

Development time from egg to adult i.e. emergence from egg at $25^{\circ} \mathrm{C}$ was observed between $\left(F_{1}\right) 4.22$ to 4.01 days $\left(F_{10}\right)$, at $28^{\circ} \mathrm{C}$ the development time recorded was $\left(\mathrm{F}_{1}\right) 3.75$ to 4.17 days $\left(\mathrm{F}_{10}\right)$ and at $30^{\circ} \mathrm{C}$ the development time was observed between $\left(\mathrm{F}_{1}\right)$ 3.71 to 3.17 days $\left(\mathrm{F}_{10}\right)$ and $32^{\circ} \mathrm{C}$ the development days was observed between $\left(\mathrm{F}_{1}\right)$ 2.47 to 1.77 days $\left(\mathrm{F}_{10}\right)$.

Emergence $\%$ at $25^{\circ} \mathrm{C}$ was observed between 83.75 to $74.52 \%\left(\mathrm{~F}_{1}\right.$ to $\left.\mathrm{F}_{10}\right)$, at $28^{\circ} \mathrm{C}$ the emergence was seen between 75.61 to $68.41 \%$ $\left(\mathrm{F}_{1}\right.$ to $\left.\mathrm{F}_{10}\right)$, at $30^{\circ} \mathrm{C}$ the emergence was seen as 71.75 to $62.57 \%\left(\mathrm{~F}_{1}\right.$ to $\left.\mathrm{F}_{10}\right)$ and at $32^{\circ} \mathrm{C}$ the emergence was seen as 71.55 to $57.12 \%$ ( $\mathrm{F}_{1}$ to $\mathrm{F}_{10}$ ). 
Table.1 Percent parasitisation, development time (egg to adult), emergence rate and adult longevity of T. Chilonis at different temperatures for ten generations

\begin{tabular}{|c|c|c|c|c|c|c|c|c|c|c|c|c|c|c|c|c|c|c|c|c|}
\hline \multirow{3}{*}{$\begin{array}{c}\text { Temp } \\
(\text { in } \quad \text { C) }\end{array}$} & \multicolumn{20}{|c|}{ Generation of $T$. chilonis from $F_{1}$ to $F_{5}$} \\
\hline & \multicolumn{4}{|c|}{$\mathrm{F}_{1}$} & \multicolumn{4}{|c|}{$\mathrm{F}_{2}$} & \multicolumn{4}{|c|}{$\mathrm{F}_{3}$} & \multicolumn{4}{|c|}{$\mathrm{F}_{4}$} & \multicolumn{4}{|c|}{$\mathrm{F}_{5}$} \\
\hline & I & II & III & IV & $\mathrm{I}$ & II & III & IV & I & II & III & IV & $\mathrm{I}$ & II & III & IV & $\mathrm{I}$ & II & III & IV \\
\hline 25 & 83.61 & 2.67 & 80.41 & 3.45 & 83.21 & 3.01 & 76.21 & 3.51 & 83.64 & 2.64 & 75.21 & 3.24 & 83.25 & 2.58 & 74.21 & 3.18 & 80.61 & 2.62 & 73.24 & 3.28 \\
\hline 28 & 80.41 & 2.32 & 73.57 & 3.17 & 79.40 & 2.42 & 71.82 & 2.92 & 80.41 & 2.32 & 74.44 & 2.58 & 80.21 & 2.54 & 73.42 & 2.62 & 76.42 & 2.48 & 73.43 & 2.62 \\
\hline 30 & 79.61 & 2.14 & 67.75 & 2.57 & 76.61 & 2.11 & 68.84 & 2.31 & 76.01 & 1.64 & 65.62 & 2.24 & 74.21 & 1.68 & 68.44 & 2.12 & 75.80 & 1.52 & 68.64 & 2.12 \\
\hline 32 & 70.75 & 1.55 & 63.75 & 1.55 & 69.40 & 1.42 & 63.41 & 1.63 & 68.42 & 1.28 & 63.44 & 1.76 & 69.34 & 1.38 & 62.63 & 1.56 & 68.23 & 1.34 & 61.27 & 1.58 \\
\hline Mean & 78.55 & 1.73 & 71.37 & 2.67 & 77.15 & 2.23 & 70.05 & 2.59 & 77.11 & 1.97 & 69.65 & 1.95 & 76.55 & 2.03 & 69.65 & 1.89 & 75.24 & 1.99 & 69.05 & 2.39 \\
\hline $\operatorname{SEm}( \pm)$ & 0.43 & 0.10 & 1.36 & 0.12 & 0.77 & 0.08 & 0.74 & 0.04 & 1.12 & 0.10 & 1.13 & 0.07 & 1.00 & 0.12 & 1.07 & 0.05 & 1.17 & 0.10 & 0.58 & 0.10 \\
\hline $\mathrm{SE}(\mathrm{d})$ & 0.60 & 0.14 & 1.92 & 0.17 & 1.29 & 0.12 & 1.04 & 0.06 & 1.58 & 0.14 & 1.60 & 0.10 & 1.41 & 0.16 & 1.52 & 0.08 & 1.66 & 0.15 & 0.82 & 0.14 \\
\hline $\mathrm{CD}_{0.05}$ & 1.27 & 0.31 & 4.04 & 0.36 & 2.31 & 0.24 & 2.19 & 0.13 & 3.35 & 0.29 & 3.36 & 0.21 & 2.98 & 0.34 & 3.19 & 0.16 & 3.50 & 0.30 & 1.73 & 0.31 \\
\hline \multirow{3}{*}{$\begin{array}{l}\text { Temp } \\
(\text { in C) }\end{array}$} & \multicolumn{20}{|c|}{ Generation of $T$. chilonis from $\mathrm{F}_{6}$ to $\mathrm{F}_{10}$} \\
\hline & \multicolumn{4}{|c|}{$\mathrm{F}_{6}$} & \multicolumn{4}{|c|}{$\mathrm{F}_{7}$} & \multicolumn{4}{|c|}{$\mathrm{F}_{8}$} & \multicolumn{4}{|c|}{$\mathrm{F}_{9}$} & \multicolumn{4}{|c|}{$\mathrm{F}_{10}$} \\
\hline & I & II & III & IV & I & II & III & IV & I & II & III & IV & I & II & III & IV & I & II & III & IV \\
\hline 25 & 81.24 & 2.81 & 72.37 & 3.24 & 80.61 & 3.12 & 69.81 & 3.12 & 79.62 & 2.44 & 70.64 & 3.34 & 79.21 & 2.52 & 69.24 & 3.36 & 78.71 & 2.42 & 70.25 & 3.14 \\
\hline 28 & 76.82 & 2.38 & 72.01 & 2.34 & 75.62 & 2.42 & 69.23 & 2.48 & 78.64 & 2.58 & 66.45 & 2.32 & 75.81 & 2.28 & 66.23 & 2.32 & 76.54 & 2.46 & 67.64 & 2.55 \\
\hline 30 & 74.63 & 1.62 & 63.42 & 2.16 & 74.83 & 1.58 & 62.45 & 1.68 & 74.89 & 1.64 & 60.83 & 1.46 & 72.26 & 1.68 & 61.24 & 1.68 & 71.25 & 1.85 & 59.24 & 1.97 \\
\hline 32 & 65.40 & 1.28 & 54.24 & 1.52 & 65.24 & 1.38 & 56.45 & 1.38 & 66.41 & 1.41 & 52.61 & 1.36 & 63.84 & 1.44 & 54.42 & 1.44 & 62.25 & 1.47 & 52.51 & 1.38 \\
\hline Mean & 74.54 & 2.024 & 65.43 & 2.30 & 74.05 & 2.12 & 64.35 & 2.16 & 74.61 & 2.01 & 62.62 & 2.12 & 72.62 & 1.98 & 62.72 & 2.19 & 71.7 & 2.01 & 62.45 & 2.21 \\
\hline $\operatorname{SEm}( \pm)$ & 1.46 & 0.11 & 0.72 & 0.11 & 1.08 & 0.08 & 1.31 & 0.08 & 0.87 & 0.12 & 0.79 & 0.09 & 1.28 & 0.09 & 1.29 & 0.07 & 1.31 & 0.09 & 0.81 & 0.72 \\
\hline $\mathrm{SE}(\mathrm{d})$ & 2.06 & 0.15 & 1.02 & 0.14 & 1.53 & 0.12 & 1.84 & 0.12 & 1.23 & 0.17 & 1.11 & 0.13 & 1.80 & 0.13 & 1.83 & 0.09 & 1.85 & 0.13 & 1.14 & 0.09 \\
\hline $\mathrm{CD}_{0.05}$ & 4.34 & 0.32 & 2.15 & 0.31 & 3.22 & 0.24 & 3.89 & 0.25 & 2.61 & 0.36 & 2.36 & 0.27 & 3.81 & 0.28 & 3.86 & 0.19 & 3.91 & 0.27 & 2.41 & 0.20 \\
\hline
\end{tabular}


Table.2 Percent parasitisation, development time (egg to adult), emergence rate and adult longevity of T. japonicum at different temperatures for ten generations

\begin{tabular}{|c|c|c|c|c|c|c|c|c|c|c|c|c|c|c|c|c|c|c|c|c|}
\hline \multirow{3}{*}{$\begin{array}{l}\text { Temp } \\
(\text { in C) }\end{array}$} & \multicolumn{20}{|c|}{ Generation of $T$. japonicum from $F_{1}$ to $F_{5}$} \\
\hline & \multicolumn{4}{|c|}{$\mathrm{F}_{1}$} & \multicolumn{4}{|c|}{$\mathrm{F}_{2}$} & \multicolumn{4}{|c|}{$\mathrm{F}_{3}$} & \multicolumn{4}{|c|}{$\mathrm{F}_{4}$} & \multicolumn{4}{|c|}{$\mathrm{F}_{5}$} \\
\hline & I & II & III & IV & I & II & III & IV & I & II & III & IV & I & II & III & IV & I & II & III & IV \\
\hline 25 & 82.12 & 4.22 & 83.75 & 2.40 & 81.02 & 4.06 & 82.54 & 16.24 & 80.64 & 4.28 & 82.21 & 16.12 & 80.84 & 4.02 & 81.64 & 3.08 & 78.81 & 4.04 & 81.45 & 3.56 \\
\hline 28 & 75.03 & 3.75 & 75.61 & 2.67 & 74.84 & 3.71 & 75.43 & 14.96 & 75.64 & 3.72 & 74.65 & 15.12 & 70.66 & 3.92 & 75.86 & 2.51 & 71.22 & 3.84 & 76.24 & 2.74 \\
\hline 30 & 63.51 & 3.71 & 71.75 & 2.15 & 62.21 & 3.76 & 66.75 & 12.44 & 61.66 & 3.58 & 69.45 & 12.32 & 60.84 & 3.58 & 67.41 & 1.69 & 58.65 & 3.74 & 67.81 & 1.66 \\
\hline 32 & 53.21 & 2.47 & 71.55 & 1.62 & 54.23 & 2.23 & 64.63 & 10.84 & 56.44 & 2.42 & 64.86 & 11.28 & 52.26 & 2.32 & 64.45 & 1.34 & 48.66 & 2.14 & 63.42 & 1.33 \\
\hline Mean & 68.81 & 3.53 & 75.5 & 2.21 & 68.75 & 3.43 & 72.45 & 2.53 & 68.58 & 3.56 & 72.77 & 2.05 & 66.0 & 3.46 & 72.34 & 2.15 & 64.34 & 3.42 & 72.52 & 2.32 \\
\hline $\operatorname{SEm}( \pm)$ & 1.13 & 0.05 & 1.05 & 0.27 & 1.05 & 0.06 & 1.29 & 0.33 & 1.02 & 0.09 & 0.71 & 0.23 & 0.69 & 0.07 & 0.92 & 0.28 & 0.96 & 0.03 & 0.68 & 0.34 \\
\hline SE(d) & 1.59 & 0.08 & 1.48 & 0.38 & 1.49 & 0.09 & 1.82 & 0.47 & 1.43 & 0.12 & 0.99 & 0.32 & 0.98 & 0.11 & 1.30 & 0.41 & 1.35 & 0.05 & 0.96 & 0.48 \\
\hline $\mathrm{CD}_{0.05}$ & 3.36 & 0.17 & 3.14 & 0.80 & 3.15 & 0.21 & 3.85 & 1.01 & 3.02 & 0.27 & 2.10 & 0.69 & 2.07 & 0.22 & 2.75 & 0.84 & 2.86 & 0.12 & 2.03 & 1.02 \\
\hline \multirow{3}{*}{$\begin{array}{l}\text { Temp } \\
(\text { in } \mathrm{C})\end{array}$} & \multicolumn{20}{|c|}{ Generation of $T$. japonicum from $\mathrm{F}_{6}$ to $\mathrm{F}_{10}$} \\
\hline & \multicolumn{4}{|c|}{$\mathrm{F}_{6}$} & \multicolumn{4}{|c|}{$\mathrm{F}_{7}$} & \multicolumn{4}{|c|}{$\mathrm{F}_{8}$} & \multicolumn{4}{|c|}{$\mathrm{F}_{9}$} & \multicolumn{4}{|c|}{$\mathrm{F}_{10}$} \\
\hline & I & II & III & IV & I & II & III & IV & I & II & III & IV & I & II & III & IV & I & II & III & IV \\
\hline 25 & 78.23 & 4.08 & 81.4 & 2.78 & 74.44 & 3.98 & 77.44 & 3.67 & 69.41 & 4.06 & 76.21 & 3.37 & 69.24 & 3.74 & 74.44 & 3.44 & 69.25 & 4.01 & 74.52 & 2.63 \\
\hline 28 & 70.64 & 3.92 & 74.23 & 2.79 & 66.42 & 3.88 & 72.85 & 2.84 & 65.65 & 3.56 & 70.26 & 2.54 & 62.23 & 3.98 & 69.67 & 2.44 & 60.75 & 4.17 & 68.41 & 2.48 \\
\hline 30 & 57.46 & 3.46 & 68.81 & 1.70 & 55.61 & 3.16 & 65.24 & 1.83 & 53.26 & 2.96 & 65.80 & 1.81 & 52.84 & 3.32 & 63.41 & 1.70 & 51.50 & 3.17 & 62.57 & 1.65 \\
\hline 32 & 46.41 & 2.08 & 63.26 & 1.29 & 46.45 & 1.84 & 62.41 & 1.28 & 45.24 & 1.68 & 62.86 & 1.24 & 43.84 & 1.84 & 56.45 & 1.21 & 42.75 & 1.77 & 57.12 & 1.19 \\
\hline Mean & 63.10 & 3.38 & 71.81 & 2.14 & 60.74 & 3.20 & 69.45 & 2.39 & 58.39 & 3.06 & 68.54 & 2.23 & 56.90 & 3.21 & 65.95 & 2.20 & 56.15 & 3.35 & 65.7 & 2.18 \\
\hline $\operatorname{SEm}( \pm)$ & 0.77 & 0.06 & 0.57 & 0.33 & 1.33 & 0.11 & 0.85 & 0.41 & 1.35 & 0.12 & 0.77 & 0.33 & 1.20 & 0.09 & 0.73 & 0.32 & 0.79 & 0.11 & 0.75 & 0.30 \\
\hline SE(d) & 1.08 & 0.09 & 0.80 & 0.47 & 1.88 & 0.14 & 1.18 & 0.57 & 1.90 & 0.17 & 1.0 & 0.47 & 1.70 & 0.12 & 1.03 & 0.45 & 1.12 & 0.16 & 1.05 & 0.43 \\
\hline $\mathrm{CD}_{0.05}$ & 2.29 & 0.20 & 1.69 & 1.0 & 3.97 & 0.31 & 2.48 & 1.22 & 4.02 & 0.36 & 2.31 & 0.99 & 3.58 & 0.27 & 2.17 & 0.96 & 2.37 & 0.34 & 2.23 & 0.91 \\
\hline
\end{tabular}

Temp. $=$ Temperature,$\quad \mathrm{I}=$ percent parasitisation $(\%), \quad \mathrm{II}=$ Development time $($ Days $), \quad$ III $=$ Emergence rate $(\%), \quad$ IV = Adult longevity $($ Days $)$ 
Adult longevity at $25^{\circ} \mathrm{C}$ was observed between 2.40 to 2.63 days $\left(\mathrm{F}_{1}\right.$ to $\left.\mathrm{F}_{10}\right)$, at $28^{\circ} \mathrm{C}$ the longevity was seen between $\left(\mathrm{F}_{1}\right) 2.67$ to 2.48 days $\left(\mathrm{F}_{10}\right)$ and $30^{\circ} \mathrm{C}$ the longevity was marked between $\left(F_{1}\right) 2.15$ to 1.65 days $\left(F_{10}\right)$ and at $32^{\circ} \mathrm{C}$ the longevity was observed between $\left(F_{1}\right) 1.62$ to 1.19 days $\left(F_{10}\right)$.

In both the species with the increase in temperature the decrease in percent parasitisation, emergence percent and the duration of life cycle was observed. The changes in the life cycle were observed as decrement in time of development from egg to adult and decrease in adult longevity. With the passing generations in the laboratory, affect on the efficacy of the parasitoid was marked.

\section{References}

Baitha A and Ram A. 1998. Life table studies on Trichogrammatoidea sp. nr. armigera Nagaraja an egg parasitoid of Helicoverpa armigera, Indian Journal of Entomology, 60: 250-256.

Consoli F L and Parra J R.1995. Effects of constant and alternating temperatures on Trichogramma galloi Zucchi (Hymenoptera. Trichogrammatidae) biology, Development and thermal requirements, Journal of Applied Entomology, 119: 415-418.

DeBach P. Chapman and Hall; London, UK: 1964. Biological control of insect pests and weeds.

Garcia P and Tavares J. 1994. Parasitic capacity, longevity and development of Trichogramma cordubensis (Hymenoptera: Trichogrammatidae) at three temperature regimes, Les Colloques de l'INRA, 73: 4-7.

Hawkins BA and Smith JW. 1986. Rhaconotus roslinensis (Hymenoptera: Braconidae), a candidate for biological control of stalk boring sugarcane pests (Lepidoptera: Pyralidae): development, life tables and intraspecific competition, Annals of the Entomological Society of America, 79: 905-911.

Hou M, Wang F, Zhang F and Wan F. 2006. Parasitism of Helicoverpa assulta eggs by Trichogramma spp.: implications for inundative release, Appl. Entomol. Zool., 41: 577-584.

Jervis MA and Copland MJW. 1996. In M. A. Jervis and N. A. Kidd (Eds.), Insect natural enemies: Practical approaches to their study and evaluation (pp. 63161). London, UK: Chapman \& Hall.

Li L. 1994. Worldwide use of Trichogramma for biological control on different crops: a survey. In: Wajnberg E, Hassan SA (Eds.), Biological control with egg parasitoids, CAB International, Wallingford, 37-53.

McDougall SJ and Mills J. 1997. The influence of hosts, temperature and food sources on the longevity of Trichogramma platneri, Entomologia Experimentalis et Applicata, 83: 195203.

Mills NJ and Kuhlmann U. 2000. The relationship between egg load and fecundity among Trichogramma parasitoids, Ecological Entomology, 25:315-324.

Nagarkatti S and Nagaraja HL. 1978. Experimental comparison of laboratory reared vs. wild type Trichogramma confusum (Hym., Trichogrammatidae) Fertility, cumulative fertility and longevity, Entomophaga, 23: 129-136.

Pak G and Oatman ER. 1982. Comparative life table behaviour and competition studies of Trichogramma brevicapillum and Trichogramma pretiosum. Entomologia Experimentalis et Applicata, 32: 6879.

Pintureau B and Bolland P.2001. Response to selection for a high or a low sex ratio 
in Wolbachia-infected lines of Trichogramma cordubensis subjected to high temperature, Vestnik Zoologii, 35: 83-86.

Rao PK and Ali MH. 1977. Influence of certain climatic factors on the egg parasites of the rice stem borer, Indian journal of Entomology, 37: 362-366.

Stinner RE, Ridgway R L and Morrison R K. 1974. Longevity, fecundity, and searching ability of Trichogramma pretiosum reared by three methods, Environmental Entomology, 3: 558560.

Van Lenteren JC. 2000. Success in biological control of arthropods by augmentation of natural enemies, Biological Control: Measures of Success. Kluwer Academic Publishers, Dordrecht, pp. $77-103$.

Yuan XH, Song LW, Zhang JJ, Zang LS, Zhu L, Ruan CC and Sun GZ. 2012. Performance of four Chinese Trichogramma species as biocontrol agents of the rice striped stem borer, Chilo suppressalis, under various temperature and humidity regimes, Journal of Pest Science, 85(4): 497504.

\section{How to cite this article:}

Mohanisha Janghel, P.C. Dash and Samal, K.C. 2019. Effect of Different Temperatures on Growth and Development of Trichogramma. Int.J.Curr.Microbiol.App.Sci. 8(11): 2119-2125. doi: https://doi.org/10.20546/ijcmas.2019.811.246 